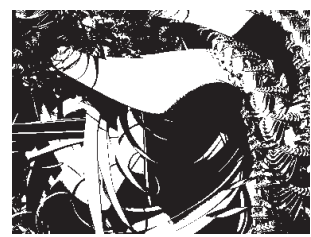

doi:10.5559/di.20.1.01

\title{
SEKTOR \\ ZAPOSLENOSTI ŽENA I FERTILITET \\ U HRVATSKOJ
}

Anđelko AKRAP

Ekonomski fakultet, Zagreb

UDK: $331.101 .232-055.2(497.5)$

$331.101 .25-055.2(497.5)$

$314.17(497.5): 331$

$314.145(497.5): 331$

Izvorni znanstveni rad

Primljeno: 7. 7. 2010.

Osnovni cili rada jest analiza međusobne povezanosti između sektora zaposlenosti žena i fertiliteta u Hrvatskoj. Istraživanje je provedeno kvantitativnom i kvalitativnom analizom.

Kvantitativno istraživanje temelii se na proporcionalnom kvotnom uzorku od 1309 zaposlenih žena u dobi od 20 do 39 godina. Kvalitativno istraživanje provedeno je metodom dubinskog intervjua na uzorku od 20 sudionica. Prije analize dan je teorijski i kvantitativni pregled rijetkih recentnih europskih istraživanja o tematiziranom problemu. $\mathrm{Na}$ manifestnoj razini među promatranima sektorima djelatnosti nisu nađene (statistički) značajne razlike u fertilitetnoj motivaciji (zbroj ostvarenoga i namjeravanoga fertiliteta). Unatoč tome pokazano je da je sektor dielatnosti važan razlog odgode rađanja, posebno u sektoru trgovine. Državni sektori (zdravstvo i obrazovanje) pružaju određenu sigurnost i ondje nalazimo najmanji udio žena koje ne žele djecu, dok je istodobno u privatnom sektoru (posebno financijsko posredovanje) udio žena koje ne žele djecu značajno viši. $U$ radu je pokazana i povezanost atipičnoga radnog vremena, točnije: rada prekovremeno, i smanjenoga fertiliteta, dok nije utvrđena značajna povezanost fertiliteta i rada vikendom.

Ključne riječi: fertilitet, sektor zaposlenosti žena, zaposlena žena, atipično radno vrijeme

Anđelko Akrap, Ekonomski fakultet Sveučilišta u Zagrebu, Trg J. F. Kennedyja 6, 10000 Zagreb, Hrvatska. E-mail: aakrap@efzg.hr 
Zapošljavanje žena na plaćeni posao izvan kućanstva nedvojbeno je činitelj koji je, izravno ili neizravno, uvelike unio osjetne promjene u svijet obitelji i rada. Prvotno se ulazak žena na tržište rada smatrao privremenom pojavom radi popunjavanja kućnoga budžeta (Hakim, 2003.), no ubrzo se pokazalo da to nije tek privremena pojava, nego da je valja promatrati u sklopu razvojnih učinaka modernizacijskoga procesa. Masovniji izlazak žena na tržište rada uslijedio je od sredine 1960-ih (Mendras, 2004.). Otada je zamjetno ubrzan, ne samo proces promjene spolne strukture zaposlenih nego su se pojavili novi, zaista brojni, činitelji koji utječu na fertilitetno ponašanje. Sirenjem društva masovne potrošnje razvijale su se i nove djelatnosti koje su povećavale potražnju za ženskom radnom snagom. Hrvatska je, u odnosu na današnje visokorazvijene europske zemlje, kao i velika većina nekadašnjih socijalističkih zemalja u vrlo kratkom vremenu, osobito od 1960-ih, vrlo ubrzano mijenjala ekonomsko-socijalnu i demografsku strukturu (Wertheimer-Baletić, 1990.). Iako je rastao broj zaposlenih izvan poljoprivrede, sve do promjene političkoga i gospodarskoga sustava 1990. i prijelaza na tržišno gospodarstvo struktura zaposlenih po djelatnostima gotovo se nije mijenjala (Matković, 2003.). Nakon toga uslijedile su ne samo dinamične promjene $\mathrm{u}$ strukturi zaposlenih po djelatnostima nego i u strukturi radnoga vremena, osobito u djelatnostima u kojima je rasla zaposlenost žena.

Ako ima djecu, zaposlena žena živi u pravoj dvojbi između prevelikih zahtjeva koji joj se postavljaju (zbog kumulacije uloga - zaposlena žena, majka, supruga, kućanica) i osamljenja (zbog gubitka važnoga interakcijskog polja pri napuštanju zaposlenosti). Ta se dvojba gotovo i ne može riješiti u okviru same obitelji (Hoffman-Nowotny, 1980.), jer patrijarhalno-agrarni kulturni sklop podržava tradicionalne odnose koji se temelje na jasnim razlikama uloga po spolu, dobi i položaju u obitelji. Pod pritiskom gospodarskih i društvenih razvojnih procesa postupno se mijenja, povijesno ukorijenjena, podjela na muškarca kao glavu i hranitelja obitelji i ženu isključivo u funkciji kućanice i majke. Zapošljavanjem na plaćeni posao izvan kuće žene postaju ekonomski neovisnije, no i dalje im u većini slučajeva ostaje teret kućanskih poslova. Stoga u mnogim razvijenim zemljama, u odnosu na razdoblje prije 1960-ih, postaje sve očitija činjenica da odluku o broju djece i trenutku kada će imati djecu u većem broju slučajeva donosi žena (Hakim, 2003.). Nizak fertilitet može se razumjeti samo u kontekstu istraživanja međusobne interakcije tržišta rada, obitelji i države (Esping-Andersen, 1999.). Očito je, dakle, da u okviru toga važno mjesto zauzima usklađivanje profesionalnoga i obiteljskoga života. Veće ili manje mogućnosti u usklađivanju obiteljskoga i profesionalnoga života ovise o društvenom kontekstu. On nije jednak u pojedinim europskim državama i ovisi o mogućnosti rada s flek- 
DRUŠ. ISTRAŽ. ZAGREB GOD. 20 (2011), BR. 1 (111)

STR. 3-23

AKRAP, A.: SEKTOR ZAPOSLENOSTI... sibilnim i nepunim radnim vremenom, dostupnosti i priuštivosti centara za skrb o djeci, sustavima obiteljske politike, podjeli rada u obitelji, ekonomskoj situaciji i sigurnosti poslova i sl.

Općepoznata je činjenica da je u Europi fertilitet nizak (mjeren totalnom stopom fertiliteta - TFR) i rijetke su europske zemlje koje imaju TFR iznad razine potrebne za jednostavnu zamjenu generacija. Činjenica je da između pojedinih europskih zemalja postoje nezanemarive razlike, jer najviši fertilitet imaju najrazvijenije europske zemlje poput Norveške, Švedske i Danske, a potonje imaju i najviše stope zaposlenosti ženskoga stanovništva u fertilnoj dobi (vidjeti Eurostat, 2010.). Međutim, u razvijenim državama s relativno povoljnim fertilitetom znatan je udio žena koje rade s nepotpunim radnim vremenom. U pitanju su prije svega skandinavske zemlje, koje imaju, uz dobro razrađene pronatalitetne obiteljske politike (Neyer i Andersson, 2008.), viši stupanj jednakosti spolova, što pozitivno utječe na fertilitet (McDonald, 2000.). Rijetka iznimka između najrazvijenijih europskih država koje nemaju viši fertilitet jest Njemačka. Anne Gauthier (1996.) misli da je za takvo stanje u Njemačkoj kriv tzv. "protradicionalni model" obiteljske politike. Pokazalo se da su izrazito niske fertilitetne aspiracije u Njemačkoj unatoč dugačkom trajanju rodiljnih dopusta (Stropnik i Sambt, 2007.) u velikoj mjeri posljedica tradicionalne podjele rada među spolovima i neomogućavanja jednakopravnoga položaja žena na tržištu rada. Njemačka je tradicionalna država blagostanja bez razvijenih javnih politika skrbi za djecu koje bi podupirale usklađivanje obiteljskoga života i plaćenoga rada. Zato su žene u Njemačkoj kada rode uglavnom prisiljene privremeno napustiti posao. To pokazuje kako, bez odgovarajuće javne infrastrukture koja će omogućiti usklađivanje obiteljskoga života i plaćenoga rada, samo novčani poticaji nisu dovoljni. Njemačka unutar Europske unije pripada skupini zemalja s najslabijom institucionalnom podrškom obiteljima s djecom (Dorbritz, 2008.). Ova kratka digresija s osvrtom na Njemačku pomaže u konceptualizaciji teze da je institucionalna podrška zaposlenoj ženi majci od velike važnosti u pokušaju podizanja niskih stopa fertiliteta. Institucionalna podrška posebno dolazi do izražaja ako je žena s djecom zaposlena u sektoru gdje se često radi prekovremeno i vikendom.

$\mathrm{U}$ pogledu institucionalne skrbi o djeci zaposlenih majki situacija je u Hrvatskoj, uz stambene probleme i nezaposlenost mladih, zamjetno nepovoljnija u odnosu na zemlje s relativno povoljnim fertilitetnim trendovima. Ustanove koje pokrivaju razne oblike usluga u skrbi o djeci ni kapacitetom ni radnim vremenom ne prate potrebe zaposlenih žena kako bi se uskladile njihove radne obveze i obiteljski život (vidjeti Matković, 2007.; Dobrotić i dr., 2010.). Tomu treba dodati sljedeći problem: sve rašireniju pojavu zapošljavanja mladih žena na određeno vrijeme, što djeluje obeshrabrujuće na ulazak u brak i rađanje dje- 
DRUŠ. ISTRAŽ. ZAGREB GOD. 20 (2011) BR. 1 (1 111$)$

STR. 3-23

AKRAP, A.: SEKTOR ZAPOSLENOSTI.. ce. Upravo to potvrđuje istraživanje Esping-Andersena (2002.), koje je pokazalo kako zapošljavanje na određeno vrijeme i nesigurnost posla destimulativno djeluju na fertilitet. S druge strane, poslovi u javnom sektoru osiguravaju određenu stabilnost, stoga žene zaposlene $u$ ovom sektoru imaju veće fertilitetne aspiracije, poglavito u državama blagostanja (Esping-Andersen, 2002.).

Zaposlene žene ne možemo promatrati kao homogenu skupinu (Bernardi, 1998., cit prema Martín García, 2010.). Upravo je ova konstatacija vrlo važno za analizu u ovom radu. Utjecaj rodne segregacije na razliku u plaćama, profesionalnu pokretljivost i sl. prilično je istraženo područje u okviru sociologije i ekonomije. Istodobno su vrlo rijetka istraživanja o utjecaju rodne segregacije prema zanimanjima na fertilitet (Martín García, 2010.). Stoga je Martín García (2010.) istraživala koliko rodna segregacija posebno tipičnih ženskih zanimanja utječe na odluku o sljedećem djetetu. Neke su studije dovele u sumnju često isticanu tvrdnju prema kojoj obrazovanje i zaposlenost žena samo po sebi vodi k nižem fertilitetu (Ahn i Mira, 2002:; Engelhardt i Prskawetz, 2004.). U sklopu toga, istraživanja su pokazala da je za objašnjenje fertiliteta - i teorijski i empirijski - relevantna ne samo dostignuta razina obrazovanja nego i polje obrazovanja. O utjecaju polja obrazovanja istraživali su Martín García i Baizán (2006.) za Španjolsku, Hoem i sur. (2006.) za Švedsku, a Lappegard (2006.) za Norvešku. Sve su ove studije pokazale da ako zaposlena žena obavlja zanimanje koje je orijentirano na skrb o ljudima ili s njima imaju intenzivne socijalne kontakte, postoji pozitivna veza između obavljanja spomenutih zanimanja te broja i želje za imanjem djece. Prema Esping-Andersenu (2007.), mlade žene s jakom sklonosti prema stvaranju vlastite obitelji mogu usto težiti ne samo usavršavanju nego i karijeri, ali će vrlo vjerojatno izabrati studij i posao koji će biti najkomatibilniji s majčinstvom. S druge strane, poslovi u kojima dominiraju muškarci imaju uglavnom više plaće, radne su norme zahtjevnije i često je radna kultura muška, pa je i fertilitetna motivacija manja (Hoem i sur., 2006.).

Analitički razlozi upućuju na istraživanje koje pokazuje da žene zaposlene u obrazovnim i zdravstvenim profesijama, koje se tradicionalno smatraju ženskim zanimanjima jer su uvjeti rada pogodniji za usklađivanje obiteljskoga i poslovnoga života, češće imaju viši fertilitet (Martín García, 2010.). Statistički podaci o udjelu zaposlenih žena prema sektorima djelatnosti u odabranim europskim zemljama pokazuju kako u onim zemljama gdje je značajno veći broj žena zaposlenih u sektorima zdravstva, socijalne skrbi i obrazovanja u pravilu nalazimo i najviše stope fertiliteta (vidjeti Tablicu 1). Konstatacije iznesene u prethodno citiranom istraživanju nisu dovoljne za čvrstu tvrdnju o postojanju uzročno-posljedične veze, ali je to indikativan istraživački rezultat koji se može dodatno ispitati u traženju glavnih činitelja niskoga fertiliteta u Europi. Posebno je to važno 
DRUŠ. ISTRAŽ. ZAGREB GOD. 20 (2011), BR. 1 (111)

STR. 3-23

AKRAP, A.: SEKTOR ZAPOSLENOSTI..

OTABLICA

Zaposlenost žena prema sektorima dielatnosti u odabranim europskim zemliama, 2005. (udio u \%) zbog toga što nam, osim prethodno navedenog, nisu poznata druga istraživanja koja ispituju povezanost između sektora djelatnosti u kojem žena radi i fertiliteta. Najbliže su tomu prethodno navedena istraživanja o utjecaju polja obrazovanja žena na fertilitet, koja smo zbog izrazite oskudnosti literature povezane s naslovom rada i naveli.

\begin{tabular}{|c|c|c|c|}
\hline 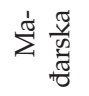 & 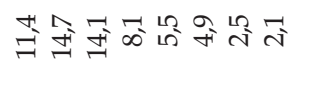 & $\begin{array}{l}\text { 足 } \\
\text { 窟 }\end{array}$ & 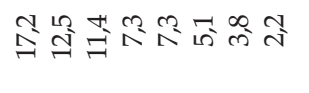 \\
\hline$\sum_{\mathfrak{Z}}^{2}$ & తి & 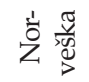 & 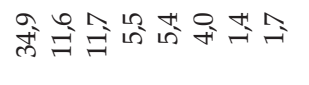 \\
\hline : & 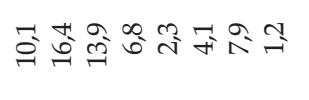 & 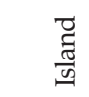 & ঐ̃a \\
\hline : & 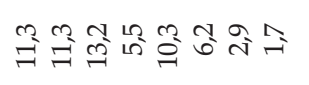 & 星曾 & Бే: \\
\hline & 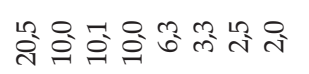 & 光 & 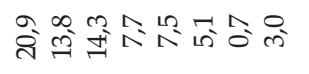 \\
\hline , & 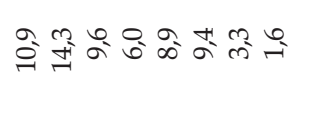 & 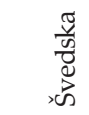 & 金令恣芯 \\
\hline & 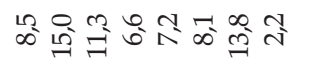 & $\frac{\pi}{0}$ & 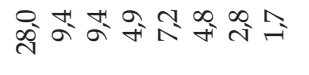 \\
\hline$\frac{\pi}{3}$ & 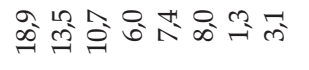 & 莺 & 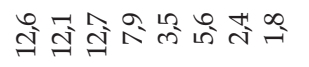 \\
\hline : & 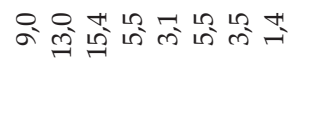 & $\begin{array}{l}\bar{\omega} \\
\dot{\omega}:=\frac{\sigma}{\tilde{z}}\end{array}$ & 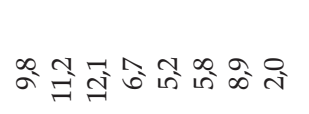 \\
\hline 穵莺 & 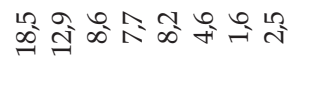 & & 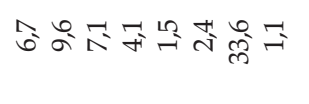 \\
\hline & 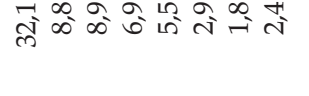 & 常 & 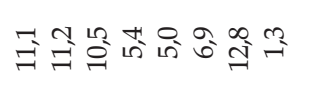 \\
\hline s & 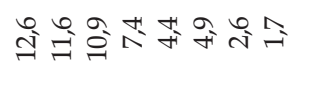 & 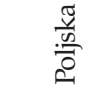 & 苍尔吢ミ゙ \\
\hline 言变 & 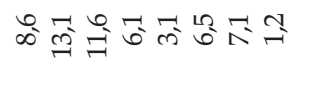 & 滛 & 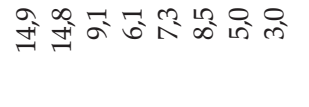 \\
\hline g & तે & 㝘 & $\begin{array}{l}\infty \\
\infty \\
\dot{d}\end{array}$ \\
\hline & 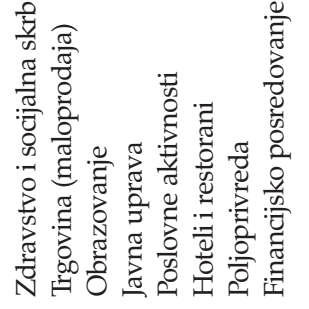 & & 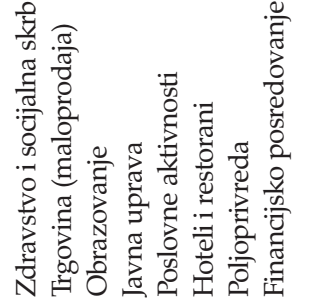 \\
\hline
\end{tabular}




\section{SVRHA I CILJEVI RADA}

Djelatnosti, kao dijelovi nacionalnoga gospodarstva, imaju specifične uvjete rada. Polazeći od te činjenice, pretpostavljamo da će sektor zaposlenosti žene utjecati na fertilitetnu motivaciju žene, što se očituje u željenom broju djece. To posebno dolazi do izražaja u situaciji nedostatne institucionalne podrške obitelji s malom djecom i neravnomjerne podjele poslova unutar obitelji. Stoga je cilj ovoga rada utvrditi/istražiti postoje li statistički značajne razlike $\mathrm{u}$ fertilitetnoj motivaciji žena od 20 do 39 godina, zaposlenih u različitim djelatnostima, prije svega u trgovini, prerađivačkoj industriji, financijskom posredovanju te obrazovanju i zdravstvu, gdje dominira ženska radna snaga. Ovim istraživanjem, dakle, namjeravamo, po djelatnostima zaposlenosti žena, identificirati za Hrvatsku specifične hipotetičke probleme i zapreke s kojima se suočava zaposlena žena u ostvarivanju željenoga broja djece. U kontekstu toga istraživanje nastoji utvrditi postoji li veza između fertilitetne aspiracije i/ili fertiliteta i sektora djelatnosti u kojima su zaposlene žene u dvadesetima i tridesetima godinama života. Namjera je za konkretne hrvatske prilike istražiti: 1) stvara li sektor zaposlenosti žene određene zapreke za imanje željenoga broja djece i 2) je li sektor zaposlenosti žene važan razlog odgode rađanja ako dosad nemaju dijete/djecu, a planiraju ih imati.

\section{HIPOTEZE ISTRAŽIVANJA}

Polazimo od hipoteze prema kojoj postoje značajno različiti uvjeti fertilitetne motivacije zaposlenih žena u pojedinim sektorima. Nadalje, druga hipoteza tvrdi da je relativno velik, i sve veći, udio žena zaposlenih u sektorima nacionalnoga gospodarstva (osobito trgovina i financijsko posredovanje) koji imaju specifičnu dnevnu strukturu radnoga vremena, što nepovoljno utječe na fertilitet i fertilitetne aspiracije. Ovu hipotezu podupire činjenica prema kojoj ustanove koje pokrivaju razne oblike usluga skrbi o djeci radnim vremenom ne prate potrebe zaposlenih žena za usklađivanje radnih i obiteljskih obveza. Prekovremeni rad u financijskom posredovanju i rad nedjeljom u trgovini po raširenosti su relativno novije i sve rasprostranjenije pojave, povezane s rastom broja zaposlenih u trgovačkim centrima i financijskom sektoru gospodarstva. Stoga su se u relativno kratkom vremenu dogodile zamjetne promjene $u$ strukturi radnoga vremena $u$ prethodno spomenutim djelatnostima, a to ne prate promjene $u$ institucionalnoj skrbi o djeci. S obzirom na to da je to po raširenosti novija pojava, veći će nepovoljni učinci, uz nepromijenjene uvjete, $\mathrm{s}$ vremenom rasti. Treća je hipoteza da u privatnim sektorima nacionalnoga gospodarstva (osobito u sektorima gdje je prisutno atipično radno vrijeme) postoji diskriminacija mladih žena koje žele imati dijete (djecu). 


\section{METODOLOGIJA ISTRAŽIVANJA}

\section{Uzorak i prikupljanje podataka}

Rad se temelji na rezultatima projekta "Povezanost fertiliteta i sektora zaposlenosti žena u Hrvatskoj", koji se provodio od veljače do travnja 2007. godine. Istraživanje u sklopu ovoga projekta provedeno je terenskim anketiranjem na reprezentativnom proporcionalnom kvotnom uzorku zaposlenih žena u svim područjima (županijama) Hrvatske. Cilj je bio odabrati uzorak koji će na najbolji način predstavljati ispitivanu populaciju. Kvote su bile žene prema sektorima djelatnosti (Nacionalna klasifikacija djelatnosti NKD-2002.). Udio svakoga sektora djelatnosti proporcionalno je određen prema udjelu žena (zaposlenih u pravnim osobama i obrtima prema statističkim priopćenjima Državnog zavoda za statistiku) zaposlenih u njima $\mathrm{u}$ vrijeme neposredno prije provođenja istraživanja. Uzorak je reprezentativan prema regionalnoj rasprostranjenosti (po županijama) zaposlenih žena. ${ }^{1}$ Kao istraživački instrument sastavljena je "Anketa o zaposlenosti žena i fertilitetu" sa 52 pitanja, koja su pokrila problematiku zaposlenih žena s djecom i zaposlenih žena koje nemaju djecu, ali žele imati djecu. Pitanja su koncipirana tako da pružaju mogućnost istraživanja činitelja fertiliteta i fertilitetnih intencija, mišljenja zaposlenih žena o rodiljnom dopustu i ostalim poticajima za rađanje, stavova ispitanica o zapošljavanju žena, radu u kućanstvu i položaju žene u obitelji i njihovu novčanom doprinosu kućanstvu, strukture njihova radnog vremena te ostale relevantne problematike povezane, izravno ili neizravno, s tematiziranom problematikom. U ovome je radu istražen tek dio navedene problematike. Oko $20 \%$ ispitanica u trenutku anketiranja živjelo je u seoskim naseljima, a 30\% u gradovima s više od 100.000 stanovnika. Preostale su ispitanice iz prigradskih naselja te malih i srednje velikih gradova. Anketiranjem je obuhvaćeno 1309 zaposlenih žena u Hrvatskoj od 20 do 39 godina, neovisno o bračnom stanju i imanju/neimanju djece, a anketiranje je provelo 70 studenata. Analiza se temelji na određenom broju pitanja i njihovih kombinacija, kako bismo potvrdili ili odbacili postavljene istraživačke hipoteze. Detaljnije o uzorku govori se u nastavku rada.

\section{Metode analize}

Najprije je provedena kvantitativna statistička analiza. Osnovna varijabla $u$ analizi jest sektor djelatnosti $u$ kojem je žena zaposlena. Istraživanje je provedeno na temelju sedam najzastupljenijih djelatnosti, odnosno u sektorima prerađivačke industrije, trgovine, financijskoga posredovanja, javne uprave, obrazovanja, zdravstva i ostalih uslužnih djelatnosti. Uspo- 
DRUŠ. ISTRAŽ. ZAGREB GOD. 20 (2011) BR. $1(111)$

STR. 3-23

AKRAP, A.: SEKTOR ZAPOSLENOSTI.. slenih u odabranim djelatnostima cilj je dobiti odgovor na pitanje: postoje li razlike $i$, ako postoje, možemo li ih protumačiti. Valja očekivati da će veća prisutnost atipičnoga radnog vremena (rad subotom i nedjeljom te čest prekovremeni rad) $\mathrm{u}$ pojedinim djelatnostima rezultirati manjim fertilitetom od željenoga. Isto tako pretpostavljamo da će veća prisutnost rada na određeno vrijeme u nekoj od djelatnosti utjecati obeshrabrujuće na rađanje djece. Preostalih 10 djelatnosti koje su grupirane pod kategorijom "ostalo" izostavljene su iz analize.

Uz navedene, $\mathrm{u}$ analizi su upotrijebljene sljedeće varijable: dobne grupe 20-29 i 30-39, broj živorođene djece (nisu rodile, s jednim, s dvoje, s troje i više djece), željeni broj djece, struktura radnoga vremena (rad prekovremeno, subotom i nedjeljom), dohodovni status i naselje (tri kategorije: selo, mali i srednji gradovi te veći i veliki gradovi).

Uz anketu je kao glavni istraživački instrument primijenjena i metoda dubinskog intervjua, rezultate kojega rabimo u znatno skraćenom obliku u razjašnjavanju ili podupiranju kvantitativnih nalaza. U novije vrijeme u demografiji ovaj tip istraživanja dobiva na važnosti (Randall i Koppenhaver, 2004.). Dubinski intervjui imaju nekoliko korisnih osobina (Knodel, 1997.). Oni pomažu potvrđivanje ili odbacivanje istraživačkih pronalazaka iz kvantitativnog istraživanja, upotpunjuju dobivene rezultate iz anketnog upitnika te daju objašnjenje za veze koje se istražuju. Intervjuirano je 20 sudionica kako bi se dobili relevantni podaci koji nisu uključeni $u$ anketu, ili se iz pitanja u anketi nisu mogli detaljnije konceptualizirati. Cilj je istražiti koliko je u Hrvatskoj prisutna diskriminacija zaposlenih žena s malom djecom. Intervjuirane su i zaposlene žene bez djece koje duže rade na određeno vrijeme te rade i subotom i nedjeljom. Intervjui su u prosjeku trajali 45 minuta.

\section{REZULTATI}

\section{Deskriptivna analiza uzorka}

Istraživanje je usredotočeno na hipotetički utjecaj sektora zaposlenosti na fertilitet i fertilitetne intencije. S obzirom na složenost razmatrane problematike i ograničenost podataka, nemoguće je konstruirati uzorak kojem se ne bi moglo prigovoriti. No to ne znači da relativiziramo značenje odabranog uzorka, naprotiv. Između sektora se, uz ostalo, jasno razabiru razlike $u$ pogledu veće ili manje prisutnosti atipičnoga radnog vremena $u$ strukturi radnoga vremena i rada na određeno vrijeme. U zadnjih 20 -ak godina došlo je do brzih i nezanemarivih promjena $u$ strukturi zaposlenih žena. U Tablici 2 prikazana je struktura uzorka prema sektorima djelatnosti i dobi ispitanica. Četiri od pet ispitanica zaposleno je $\mathrm{u}$ terci- 
DRUŠ. ISTRAŽ. ZAGREB GOD. 20 (2011), BR. $1(111)$

STR. 3-23

AKRAP, A.: SEKTOR ZAPOSLENOSTI..

\section{(1) TABLICA 2}

Broj i udio ispitanica prema sektorima djelatnosti i dobnim skupinama jarnom sektoru, dok su ostale većinom zaposlene u sekundarnom sektoru. U primarnom sektoru bilo je zaposleno samo 1,15\% ispitanica. ${ }^{2}$ Od sektora djelatnosti prema NKD-u 2002. najviše ispitanica iz ovog istraživanja $(21,7 \%)$ radilo je u sektoru trgovine, zatim u prerađivačkoj industriji $(13,7 \%)$ te u zdravstvenoj zaštiti i socijalnoj skrbi $(12,1 \%)$. S obzirom na radni status, najviše ispitanica stalno je zaposleno u privatnom sektoru $(44,0 \%)$, dok ih nešto više od trećine $(35,5 \%)$ radi u državnom sektoru. Ostalih 20,5\% povremeno je zaposleno u oba sektora ili su samostalne obrtnice.

\begin{tabular}{lrrrr}
\hline Sektor djelatnosti & Broj & Udio (u \%) & $20-29$ & $30-39$ \\
\hline Prerađivačka industrija & 179 & 13,7 & 44,7 & 55,3 \\
Trgovina & 284 & 21,7 & 47,2 & 52,8 \\
Financijsko posredovanje & 93 & 7,1 & 49,5 & 50,5 \\
Javna uprava i obrana, obvezno socijalno osiguranje & 85 & 6,5 & 37,6 & 62,4 \\
Obrazovanje & 132 & 10,1 & 43,2 & 56,8 \\
Zdravstvena zaštita i socijalna skrb & 158 & 12,1 & 49,4 & 50,6 \\
Ostale društvene, socijalne i osobne uslužne djelatnosti & 157 & 12,0 & 61,1 & 38,9 \\
Drugo & 221 & 16,9 & 48,9 & 51,1 \\
Ukupno & 1309 & 100,0 & 48,2 & 51,8 \\
& & & &
\end{tabular}

U cjelokupnoj ispitaničkoj populaciji svaka četvrta zaposlena žena radi na određeno vrijeme. Kada kontroliramo dob, uzimajući u obzir samo starije ispitanice (od 30 do 39), u tom slučaju udio žena zaposlenih na određeno pada otprilike na $15 \%$. S obzirom na status zaposlenja starijih ispitanica, našli smo statistički značajne razlike među sektorima djelatnosti $u$ kojima su žene zaposlene $\left(\chi^{2}=23,220 ; p<0,01\right)$. Sektor djelatnosti u kojem su žene natprosječno zaposlene na određeno vrijeme jest trgovina, gdje svaka četvrta zaposlena žena iz uzorka između 30 i 39 godina ima zaključen ugovor o radu na

(1) TABLICA 3

Status ugovora o radu prema sektorima dielatnosti ispitanica određeno vrijeme (Tablica 3). Osim trgovine, i u sektoru prerađivačke industrije radi natprosječan broj žena (svaka peta starija od 30 godina) s ugovorom na određeno vrijeme.

Sektor djelatnosti

Status zaposlenja (udio u \%)

Prerađivačka industrija

Određeno Određeno (30-39)*

Trgovina

$\begin{array}{rr}23,4 & 19,6 \\ 33,1 & 25,3 \\ 19,6 & 6,5 \\ 11,8 & 5,7 \\ 18,6 & 9,3 \\ 25,8 & 13,8 \\ 22,4 & 10,2 \\ 24,6 & 14,9\end{array}$

Financijsko posredovanje

Javna uprava i obrana, obvezno socijalno osiguranje

Obrazovanje

Zdravstvena zaštita i socijalna skrb

Ostale društvene, socijalne i osobne uslužne djelatnosti

Ukupno

${ }^{*} \chi^{2}(7, N=673)=23,220 ; p<0,01$ 
DRUŠ. ISTRAŽ. ZAGREB GOD. 20 (2011), BR. $1(111)$

STR. 3-23

AKRAP, A.: SEKTOR ZAPOSLENOSTI..

(1) TABLICA 4

Razdioba ispitanica s obzirom na procijenjeni dohodovni status kućanstva prema sektorima dielatnosti (udio u \%)
U odnosu na prosjek cijelog uzorka, viši udio zaposlenih žena na određeno nalazi se u sektoru zdravstva i socijalne skrbi, dakle u djelatnostima koje većinom pripadaju državnom sektoru. Pretpostavljamo da na tu pojavu utječe stažiranje, karakteristično za sektor zdravstva, pa se u skladu s potonjim udio zaposlenih na određeno vrijeme s godinama i radnim stažom smanjuje. Najmanje žena na određeno vrijeme radi u javnoj upravi i obrazovnom sektoru.

Rad na određeno vrijeme možemo donekle povezati i s dohodovnim statusom kućanstva ispitanica (Tablica 4). Prema dobivenim rezultatima, na pitanje o tvrdnji koja najbolje opisuje dohodak kućanstva ispitanica - "dovoljno novca za udoban život" - u najvećoj mjeri imaju ispitanice iz sektora obrazovanja i financijskoga posredovanja. To ne iznenađuje, jer u tim sektorima, posebno u sektoru obrazovanja, dominiraju žene sa završenim tercijarnim obrazovanjem, što uglavnom znači i viši dohodak

\begin{tabular}{lrrr}
\hline & \multicolumn{2}{c}{ Dohodovni status } \\
\cline { 3 - 4 } & Niži & Srednji & Viši \\
\hline Prerađivačka industrija & 15,2 & 66,9 & 18,0 \\
Trgovina & 16,3 & 68,4 & 15,2 \\
Financijsko posredovanje & 5,4 & 64,5 & 30,1 \\
Javna uprava i obrana, obvezno socijalno osiguranje & 9,6 & 75,9 & 14,5 \\
Obrazovanje & 2,3 & 67,2 & 30,5 \\
Zdravstvena zaštita i socijalna skrb & 6,4 & 69,2 & 24,4 \\
Ostale društvene, socijalne i osobne uslužne djelatnosti & 6,4 & 65,6 & 28,0 \\
Ukupno & 10,2 & 66,4 & 23,4 \\
\hline
\end{tabular}

S druge strane, natprosječan udio ispitanica koje su izjavile kako "teško žive i jedva spajaju kraj s krajem" nalazimo upravo u sektorima trgovine i prerađivačke industrije. Relativno niska primanja možemo objasniti obrazovnim statusom, ali i općenito niskim prosječnim primanjima žena u tim dje-

(1) TABLICA 5

Obrazovni status ispitanica prema sektorima dielatnosti (udio u \%) latnostima. Kao što pokazuje Tablica 5, kod žena zaposlenih u sektoru prerađivačke industrije nalazimo natprosječan udio žena s primarnim obrazovanjem. U sektoru trgovine najbrojnije su žene sa završenim sekundarnim obrazovanjem.

\begin{tabular}{lrrr}
\hline & \multicolumn{2}{c}{ Obrazovanje } \\
\cline { 2 - 4 } & Primarno & Sekundarno & Tercijarno \\
\hline Prerađivačka industrija & 10,1 & 69,1 & 20,8 \\
Trgovina & 1,1 & 84,5 & 14,4 \\
Financijsko posredovanje & 0,0 & 52,7 & 47,3 \\
Javna uprava i obrana, obvezno socijalno osiguranje & 1,2 & 48,2 & 50,6 \\
Obrazovanje & 1,5 & 6,1 & 92,4 \\
Zdravstvena zaštita i socijalna skrb & 0,0 & 67,1 & 32,9 \\
Ostale društvene, socijalne i osobne uslužne djelatnosti & 1,3 & 70,1 & 28,7 \\
Drugo & 4,5 & 53,2 & 42,3 \\
Ukupno & 2,8 & 60,7 & 36,5 \\
\hline
\end{tabular}




\section{Osnovni istraživački nalazi}

Prema glavnoj hipotezi u ovom radu, u Hrvatskoj postoje razlike $\mathrm{u}$ fertilitetnoj motivaciji s obzirom na sektore $\mathrm{u}$ kojima su žene zaposlene. Među sektorima zaposlenosti žena u Hrvatskoj postoje razlike $\mathrm{u}$ razini fertiliteta koje se ne mogu objasniti na temelju postojećih spoznaja, jer takva istraživanja nisu provedena. Ovo istraživanje, prvo te vrste kod nas, pokazuje da postoji statistički značajna razlika između ispitanica koje rade u pojedinim sektorima prema obilježju broja djece. Iz Tablice 7 može se uočiti da najmanje djece imaju ispitanice koje rade $\mathrm{u}$ sektoru financijskoga posredovanja, dakle u bankama i ostalim financijskim institucijama. U sektoru financijskoga posredovanja često je prisutan nenajavljen prekovremeni rad, osobito u počecima zaposlenja, što je restriktivni činitelj fertiliteta. Ž. M. (1983.) ima tercijarno obrazovanje i radi u financijskom sektoru, navodi svoja iskustva prilikom intervjua za posao: "Tražila sam posao u struci i pronašla ga u hrvatskoj privatnoj firmi. Već mi je razgovor za posao pokazao da se ne bih trebala zaposliti u toj firmi. Posao mi je hitno trebao i morala sam ga prihvatiti. Na razgovoru za posao direktorica mi je rekla da mrzi žene koje hoće raditi i odgajati djecu te da ako želim raditi kod nje ne smijem ni u kojem slučaju ostati trudna". S druge strane, osim sektora prerađivačke industrije i trgovine, gdje rade žene s nižim stupnjevima obrazovanja, najviši udio žena koje su rodile nalazimo u sektoru zdravstva i socijalne skrbi. Pri tome valja imati na umu stanovit utjecaj dobi i obrazovne strukture ispitanica, što se može vidjeti iz prethodnih tablica. Tako, primjerice, žene u sektoru trgovine trebale bi, zbog kraćega trajanja procesa obrazovanja, u prosjeku najmanje pet godina ranije početi rađati djecu od ispitanica iz obrazovnoga sektora. Ovu pojednostavnjenu interpretaciju detaljnije ćemo obrazložiti u nastavku. U analizi su zaposlene žene, u odnosu na broj djece koje imaju, podijeljene $\mathrm{u}$ četiri skupine (nula, jedno, dvoje, troje i više). Hi-kvadrat test pokazao je statistički značajnu razliku između navedenih skupina žena. Izdvojimo najvažnije nalaze. ${ }^{3}$ Žene bez djece pokazuju visoke aspiracije za imanjem dvoje djece (šest od deset ispitanica bez djece). Istodobno, svaka četvrta ispitanica koja nije rodila želi roditi barem troje djece. $S$ druge je strane fertilitetnoga spektra relativno nizak udio (oko 7\%) žena koje nemaju djecu niti ih želi imati. Tek nešto veći broj preferira samo jedno dijete.

Ovi rezultati pokazuju da su izražene preferencije za rađanje barem dvoje djece u Hrvatskoj i da nemali broj ispitanica iskazuje želju roditi više djece nego što je potrebno za jednostavnu obnovu generacije. ${ }^{4}$ No kada u analizu uključimo ispitanice koje su rodile barem jedno dijete, udio onih koje že- 
DRUŠ. ISTRAŽ. ZAGREB GOD. 20 (2011), BR. $1(111)$

STR. 3-23

AKRAP, A.:

SEKTOR ZAPOSLENOSTI..

(1) TABLICA 6

Ispitanice prema trenutačnom i

želienom broju djece prema odabranim sektorima, udio u \%

\begin{tabular}{llrrrr}
\hline \multirow{2}{*}{ Sektor djelatnosti } & & \multicolumn{3}{c}{ Koliko djece namjeravaju imati } \\
\cline { 3 - 5 } Prerađivačka industrija & Broj djece & 0 & 1 & 2 & $3+$ \\
& 0 & 5,3 & 2,6 & 65,8 & 26,3 \\
& 1 & 17,6 & 52,9 & 29,4 & 0,0 \\
Trgovina & 2 & 73,2 & 24,4 & 2,4 & 0,0 \\
& $3+$ & 93,3 & 6,7 & 0,0 & 0,0 \\
& 0 & 7,8 & 10,4 & 55,8 & 26,0 \\
Financijsko posredovanje & 1 & 20,5 & 52,3 & 22,7 & 4,5 \\
& 2 & 82,5 & 12,3 & 3,5 & 1,8 \\
& $3+$ & 87,5 & 12,5 & 0,0 & 0,0 \\
Obrazovanje & 0 & 11,8 & 11,8 & 61,8 & 14,7 \\
& 1 & 13,3 & 46,7 & 40,0 & 0,0 \\
& 2 & 68,8 & 31,2 & 0,0 & 0,0 \\
& $3+$ & 100,0 & 0,0 & 0,0 & 0,0 \\
Zdravstvo i socijalna skrb & 0 & 2,6 & 5,1 & 61,5 & 30,8 \\
& 1 & 34,8 & 43,5 & 21,7 & 0,0 \\
& 2 & 60,7 & 39,3 & 0,0 & 0,0 \\
& $3+$ & 100,0 & 0,0 & 0,0 & 0,0 \\
& 0 & 2,1 & 8,3 & 56,2 & 33,3 \\
& 1 & 15,0 & 57,5 & 22,5 & 5,0 \\
& 2 & 62,5 & 33,3 & 4,2 & 0,0 \\
& $3+$ & 66,7 & 33,3 & 0,0 & 0,0 \\
\hline
\end{tabular}

Neprijeporno je da na tu odluku utječe više činitelja. Možemo pretpostaviti, poznavajući dominirajuću srednjeobrazovnu strukturu tih žena, određen utjecaj već istaknutih uvjeta rada u ovom sektoru. Jer ako pogledamo Tablicu 7, prosječan broj djece koje su rodile ispitanice u sektoru trgovine $\mathrm{i}$ one u sektoru obrazovanja statistički se značajno ne razlikuju.

U Hrvatskoj postoje određeni sektori gdje se radni sati prilagođuju količini obavljenoga posla, pa bez obzira na to što mogu biti unaprijed određeni, u stvarnosti vrlo često odstupa- 
DRUŠ. ISTRAŽ. ZAGREB GOD. 20 (2011), BR. $1(111)$

STR. 3-23

AKRAP, A.: SEKTOR ZAPOSLENOSTI..

(1) TABLICA 7

Ispitanice prema ostvarenom i namjeravanom fertilitetu, po odabranim sektorima dielatnosti meni rad, a nerijetko i rad vikendom. Uglavnom je riječ o poslovima u sektorima bankarstva, osiguranja, revizije i ostalih financijskih usluga, $u$ kojima su zaposlene mlade visokoobrazovane žene, a zbog čuvanja zaposlenja i napredovanja na poslu odlučuju se na odgađanje majčinstva. S druge strane, $u$ jednom drugom sektoru, gdje nije potrebna visokoobrazovana ženska radna snaga, sektoru trgovine, problem je sličan, a možda i izraženiji. Zahtjevi posla u tom sektoru vrlo učestalo traže i sedmodnevno radno vrijeme s relativno malo slobodnih dana (vidjeti Tablicu 8). U nedostatku organizirane skrbi o djeci fertilitet je žena $u$ djelatnostima sa strukturom radnoga vremena gdje je teško uskladiti posao i skrb o djeci manji od očekivanoga. To potvrđuje kazivanje Š. P. (1984.), prodavačice zaposlene u trgovačkom lancu, čiji slučaj nije osamljen, nego se, $\mathrm{u}$ određenoj mjeri, može uzeti kao reprezentativan: "Što se tiče vikenda, ne treba ni pomišljat da će netko zbog djeteta te dane bit slobodan! Slobodne dane dobivaš kako stigneš, ali skoro nikad skupa nego jedan u utorak, a drugi u petak. Kod zapošljavanja, ako imaš malo dijete nemaš baš neku šansu dobit posao. Razmišljala sam o promjeni posla, ali ovdje sam nakon 3 godine dobila ugovor za stalno. Kad bih promijenila posao opet bi morala radit na ugovor, tri po tri mjeseca. Razlike u plaći su male. Voljela bih da mi smjene nisu do 22:00 navečer. Kad radim popodnevnu smjenu djecu uopće ne vidim cijeli tjedan." Rezultati također pokazuju da žene zaposlene $\mathrm{u}$ javnom sektoru (zdravstvo i socijalna skrb, obrazovanje i javna uprava), gdje radni sati pogoduju ženama koje imaju djecu i gdje napredovanje u poslu nije toliko izraženo kao $u$ privatnoj poslovnoj sferi, imaju, $\mathrm{u}$ prosjeku, više djece od zaposlenih u privatnom sektoru (posebice sektor financijskoga posredovanja).

\begin{tabular}{lrrr}
\hline Sektori djelatnosti & $\begin{array}{r}\text { Prosječno } \\
\text { djece rodile }\end{array}$ & $\begin{array}{r}\text { Još } \\
\text { namjeravaju }\end{array}$ & $\begin{array}{r}\text { Ukupno } \\
\text { (imaju i namjeravaju) }\end{array}$ \\
\hline Prerađivačka industrija & 1,26 & 1,03 & 2,29 \\
Trgovina & 0,91 & 1,20 & 2,11 \\
Financijsko posredovanje & 0,82 & 1,25 & 2,07 \\
Obrazovanje & 0,92 & 1,27 & 2,19 \\
Zdravstvena zaštita i socijalna skrb & 0,93 & 1,38 & 2,31 \\
\hline
\end{tabular}

${ }^{*}$ Napomena: provedeni post hoc Tukey HSD test nakon napravljene ANOVE: F $(7,936)=2,287$, $\mathrm{p}<0,05$, nije našao značajne razlike između promatranih sektora

Analiza strukture radnoga vremena prema odabranim sektorima djelatnosti upućuje na nekoliko konstatacija. Navečer ili noću najčešće rade žene zaposlene u sektoru zdravstva (liječnice i medicinske sestre), što je i očekivano, no uglavnom se radi o unaprijed određenom mjesečnom rasporedu. Preko- 
DRUŠ. ISTRAŽ. ZAGREB GOD. 20 (2011), BR. $1(111)$

STR. 3-23

AKRAP, A.: SEKTOR ZAPOSLENOSTI..

(1) TABLICA 8

Ispitanice prema učestalosti rada prekovremeno subotom i nedieljom vremeno najčešće rade žene zaposlene u sektoru financijskoga posredovanja (banke i ostale financijske institucije), što je relativno novija pojava. Rad subotom i nedjeljom najviše je raširen $u$ sektoru trgovine. Važno je imati na umu da je ovo po veličini relativno novija i sve rasprostranjenija pojava. Istodobno, analiza varijance pokazala je da samo rad prekovremeno možemo povezati s nižim trenutačnim fertilitetom, a žene koje tjedno ili češće rade prekovremeno $u$ prosjeku su rodile manje djece $(\mathrm{M}=0,78)$ od žena koje nemaju takvu strukturu radnoga vremena $(\mathrm{M}=0,93)$.

\section{Sektor djelatnosti}

Prekovremeno $^{*}$ Subotom $^{* *}$ Nedjeljom $^{* *}$

Prerađivačka industrija tjedno ili češće češće od jednom mjesečno

Trgovina

Financijsko posredovanje

$23,9 \quad 66,2 \quad 18,9$

Javna uprava i obrana, obvezno socijalno osiguranje

Obrazovanje

Zdravstvena zaštita i socijalna skrb

$23,2 \quad 80,9 \quad 45,7$

Ostale društvene, socijalne i osobne uslužne djelatnosti

Drugo

Ukupno

$10,3 \quad 51,2 \quad 37,2$

$24,1 \quad 58,6 \quad 21,4$

$26,5 \quad 47,9 \quad 30,4$

$21,9 \quad 53,5 \quad 26,1$

${ }^{*} \chi^{2}(42, N=1277)=81,078 ; \mathrm{p}<0,001 ;{ }^{* *} \chi^{2}(28, \mathrm{~N}=1277)=388,33 ; \mathrm{p}<0,001 ;{ }^{* * *} \chi^{2}(28, \mathrm{~N}=1277)=194,7 ;$ $\mathrm{p}<0,001$

Ženama u privatnom sektoru, svih obrazovnih skupina, prilično je otežano očuvati dosadašnje radno mjesto nakon duljeg izbivanja zbog rodiljnoga dopusta. A. V. (1979.) otkriva nam svoje iskustvo u poduzeću pošto je zatrudnjela: "Nakon završenog ekonomskog fakulteta zaposlila sam se u privatnoj tvrtki $u$ računovodstvu. Dobila sam posao srednje stručne spreme i prihvatila ga jer mi je bio važan stalni radni odnos kako bih mogla imati dijete. Kad sam ostala trudna, nitko nije imao ružnih komentara i normalno sam otišla na porodiljni. Za vrijeme mog porodiljnog našli su mi zamjenu. Kad sam se vratila rekli su mi da će zadržati moju zamjenu, a za mene nije ostalo nikakvo radno mjesto. $\mathrm{S}$ obzirom na to da nisu imali razloga dati mi otkaz, povremeno sam zamjenjivala kolegice. Tako je prošao jedan mjesec, a šef mi je svojim komentarima pokazivao kako za mene nema posla. Tako sam dala otkaz i zaposlila se u poduzeću koje se bavi proizvodnjom obuće." Žene koje kod kuće nemaju "baka-servis", tj. pomoć u usklađivanju obiteljskih i profesionalnih obveza, mogu na to reagirati smanjenim fertilitetom. Analizom na razini naselja pokazuje se da zaposlene žene starije od 30 godina koje žive u seoskim naseljima imaju u prosjeku veći broj rođene djece $\mathrm{u}$ odnosu na iste $\mathrm{u}$ gradskim naseljima, pri čemu su razlike 
(1) TABLICA 9

Naselje u kojem ispitanice žive i prosječan broj diece koje su rodile (ispitanice stariie od 30 godina) značajne samo u sektoru trgovine i granično značajne u sektoru prerađivačke industrije (vidjeti Tablicu 9). Pretpostavljamo da se to može protumačiti i većom podrškom "baka-servisa" u seoskim naseljima u odnosu na gradove. U svakom slučaju ova tablica pokazuje da u toj sferi postoje brojna otvorena pitanja koja su ovim radom tek dijelom protumačena.

\begin{tabular}{llrrr}
\hline \multirow{2}{*}{ Sektor } & Naselje & N & $\begin{array}{r}\text { Prosječno } \\
\text { djece }\end{array}$ & Test \\
\hline Prerađivačka industrija & selo & 31 & 1,90 & $\mathrm{~F}=2,903, \mathrm{p}=0,050$ \\
& mali i srednji gradovi & 49 & 1,59 & \\
& veći i veliki gradovi & 17 & 1,18 & \\
Trgovina & selo & 37 & 1,81 & $\mathrm{~F}=4,067, \mathrm{p}=0,019$ \\
& mali i srednji gradovi & 66 & 1,62 & \\
Financijsko posredovanje & veći i veliki gradovi & 45 & 1,22 & \\
& selo & 5 & 1,40 & $\mathrm{~F}=0,135, \mathrm{p}=0,874$ \\
& mali i srednji gradovi & 27 & 1,26 & \\
Obrazovanje & veći i veliki gradovi & 15 & 1,13 & \\
& selo & 12 & 1,75 & $\mathrm{~F}=2,333, \mathrm{p}=0,104$ \\
& mali i srednji gradovi & 37 & 1,38 & \\
Zdravstvo & veći i veliki gradovi & 24 & 1,08 & \\
& selo & 17 & 1,59 & $\mathrm{~F}=0,719, \mathrm{p}=0,490$ \\
& mali i srednji gradovi & 30 & 1,37 & \\
& veći i veliki gradovi & 32 & 1,25 & \\
\hline
\end{tabular}

\section{ZAKLJUČNA RAZMATRANJA}

Zaposlenost žena prema sektorima djelatnosti i njezin utjecaj na fertilitet vrlo je slabo istraženo područje. Problem diskriminacije zaposlenih žena na tržištu rada u Hrvatskoj zamjetno je bolje empirijski istraženo područje (Kerovec, 2003.; Galić i Nikodem, 2007.), međutim u okviru toga nisu se radile detaljnije analize prema sektorima djelatnosti niti se to dovodilo $\mathrm{u}$ vezu s fertilitetom. Visok udio zaposlenih žena $u$ sektoru trgovine u Hrvatskoj, gdje je nepovoljna struktura radnoga vremena, kao što je istraživanje pokazalo, ne pogoduje obiteljskom životu i obeshrabruje mlade žene da imaju željeni broj djece. U odnosu na sve preostale djelatnosti, trgovina je u Hrvatskoj jedna od najrazvijenijih, najkonkurentnijih i najdinamičnijih grana gospodarstva (HGK, 2009.). U okviru trgovačke djelatnosti nakon 2000. godine prisutna su dva, za ovo istraživanje važna procesa. Prvo, najveći apsolutni i relativni rast zaposlenosti žena između 2004. i 2008. godine zabilježen je $u$ trgovini, posebno $u$ trgovini na malo. I drugo, od ukupnoga broja zaposlenih žena u trgovini na malo 2009. godine njih $61 \%$ bilo je mlađe od 40 godina, a čak $47 \%$ imalo je izme- 
DRUŠ. ISTRAŽ. ZAGREB GOD. 20 (2011) BR. $1(1111)$

STR. 3-23

AKRAP, A.: SEKTOR ZAPOSLENOSTI.. đu 18 i 34 godine (DZS, 2010.). Dakle, došlo je do pomlađivanja dobne strukture zaposlenih žena u tom sektoru, osobito onih u središnjem reproduktivnom razdoblju. Vidjelo se iz rezultata da na manifestnoj razini među promatranima sektorima djelatnosti nisu nađene (statistički) značajne razlike $\mathrm{u}$ fertilitetnoj motivaciji (zbroj ostvarenoga i namjeravanoga fertiliteta). Unatoč tomu, pokazalo se da je sektor djelatnosti važan razlog odgode rađanja (posebno u sektoru trgovine). Štoviše, žene zaposlene u sektoru trgovine uglavnom "ostaju" na dvoje djece (najviše od svih), što s obzirom na njihovu obrazovnu strukturu pomalo iznenađuje.

Iako ne raspolažemo kvantitativnim podacima o fertilitetu zaposlenih žena po djelatnosti u, referentnim, visokorazvijenim europskim zemljama koje imaju relativno visok TFR, činjenica je da one imaju strukturu zaposlenih žena po djelatnosti gdje je moguće bolje kombinirati zaposlenost žena i skrb o djeci (vidjeti Tablicu 1). S obzirom na činjenicu da gotovo sve razvijene zemlje s povoljnijim TFR-om imaju sličnu strukturu zaposlenih žena prema djelatnostima, to može biti i slučajnost. Ipak ostaje pitanje: može li to biti samo puka slučajnost. Naravno, potonje treba povezati s mjerama obiteljske politike i ravnomjernom raspodjelom kućanskih poslova između bračnih drugova. Ako usporedimo s drugim europskim zemljama, vidi se da one zemlje koje imaju visok udio zaposlenih žena u zdravstvu i socijalnoj skrbi te obrazovanju, imaju i najviše stope fertiliteta. Hrvatska pripada skupini zemalja gdje je zaposlenost žena, u spomenutim sektorima, ispod europskoga prosjeka, posebno u zdravstvu i socijalnoj skrbi. Ne samo da postoje sektori u kojima je lakše uskladiti obiteljske i profesionalne obveze, nego se za rad $\mathrm{u}$ tim sektorima obrazuju, kako su pokazala opisana istraživanja, žene koje su sklonije rađanju djece. To je pokazalo i ovo istraživanje, no to ne znači da je to jedini činitelj i nema mjesta jakim tvrdnjama.

Pozitivna diskriminacija zaposlenih žena s malom djecom važan je činitelj fertilitetne motivacije, osobito ako su zaposlene $\mathrm{u}$ djelatnostima s nepovoljnom strukturom radnoga vremena. Istodobno, institucije za skrb o maloj djeci ne prate svojim radnim vremenom rad roditelja u tim sektorima. $\mathrm{Hr}$ vatska pripada skupini zemalja niže srednje pokrivenosti uslugama skrbi za djecu do tri godine, mnogo niže pokrivenosti nego što je to $\mathrm{u}$ skandinavskim modelima ili u kontinentalnom modelu (uz iznimku Njemačke), ali ima bolju situaciju nego što je u zemljama istočnoga Sredozemlja i u većini tranzicijskih zemalja (Matković, 2007.) Dakle, posebno je pitanje struktura radnoga vremena zaposlenih žena s malom djecom. Smatramo da je uz dobru volju poslodavaca moguća pozitivna diskriminacija zaposlenih žena koje imaju malu djecu, i to bez dodatnih, novih, troškova. Primjerice, ako je riječ o zapo- 
DRUŠ. ISTRAŽ. ZAGREB GOD. 20 (2011), BR. 1 (111)

STR. 3-23

AKRAP, A.: SEKTOR ZAPOSLENOSTI.. slenima u velikim trgovačkim lancima, može se unutrašnjom organizacijom prilagoditi radno vrijeme ženama s malom djecom. Preneseni dijelovi intervjua s nekoliko sudionica poduprli su pretpostavke o postojanju diskriminacije zaposlenih žena u situaciji kada zatrudne i odu na rodiljni dopust te onih s malom djecom. To nije rijetka i zanemariva pojava. Diskriminacija je uglavnom prisutna u privatnom sektoru kod svih obrazovnih skupina. Ono što bismo posebno istaknuli kao problem jesu uvjeti rada žena zaposlenih u sektoru trgovine. Velikom ekspanzijom trgovačkih lanaca u zadnjih 5-7 godina zamjetno je porastao broj zaposlenih u tom sektoru, ponajviše mlade ženske radne snage. Da su uvjeti rada u tom sektoru nepovoljni i demotivirajući za mlade žene koje žele imati dijete (djecu), uočljivo je ne samo iz dubinskog intervjua nego i iz rezultata kvantitativne analize. Posebno ističemo nepovoljno radno vrijeme, koje ograničuje veći broj žena u ostvarenju fertilitetne namjere. Osobito je teško ako i žena i njezin muž rade u istoj djelatnosti, što nije rijetkost. Što se tiče atipičnoga radnog vremena, rezultati su pokazali kako prekovremeni rad može smanjiti fertilitet, međutim rad vikendom nije se pokazao važnim činiteljem nižega fertiliteta. Pritom je zanimljivo da su ispitanice iz sektora obrazovanja i trgovine dosad rodile $\mathrm{u}$ prosjeku podjednako djece, što opet nije u skladu s teorijskim očekivanjima. Naime, moglo se očekivati da žene s višim stupnjevima obrazovanja, suočene s višim oportunitetnim troškovima vremena, češće odgađaju rađanje djece. No čini se da je u Hrvatskoj sve češće tako i kod žena u sektorima gdje je potrebna manje obrazovana ženska radna snaga (posebice sektor trgovine). Ako ne postoji pozitivna diskriminacija žena s malom djecom u njihovim poduzećima, odgađanje rađanja može dovesti do nižega ostvarenog fertiliteta od namjeravanoga.

Konačno, postavlja se pitanje ima li ovo istraživanje aplikativne vrijednosti i pruža li dovoljno rezultata koji bi jasno upućivali na kritične segmente $u$ pogledu fertilitetne motivacije zaposlenih žena, analizirano na razini sektora u kojem su zaposlene, i to ne samo za one žene koje trenutačno podižu djecu nego i one koje donose odluku o tome hoće li se uopće odlučiti na prvo ili sljedeće dijete. U svakom slučaju, riječ je tek o početnom koraku u dublja i kompleksnija istraživanja o vezi između sektora djelatnosti žena i fertiliteta, koja $\mathrm{su}, \mathrm{u}$ traženju uzroka niskoga fertiliteta, nedvojbeno potrebna.

1 U vrijeme istraživanja nije nam bila na raspolaganju struktura zaposlenih žena po sektorima djelatnosti i dobi. Tek potkraj 2010. godine Državni zavod za statistiku Republike Hrvatske publicirao je statističko izvješće Zaposlenost i plaće u 2009., gdje se, uz ostalo, nalazi struktura zaposlenih žena po djelatnosti i dobi. Zbog iznesenog 
DRUŠ. ISTRAŽ. ZAGREB GOD. 20 (2011) BR. $1(111)$

STR. 3-23

AKRAP, A.: SEKTOR ZAPOSLENOSTI..

ograničenja nije konstruiran reprezentativan uzorak strukture zaposlenih djelatnosti žena po djelatnosti od 20 do 39 godina. Uzorak $\mathrm{u}$ ovom istraživanju temelji se na podacima iz popisa stanovništva iz 2001. Pri tome se vodilo računa o tome da odstupanja u reprezentativnosti zaposlenih žena od 20 do 39 godina prema sektorima djelatnosti nisu viša od 3 postotna boda. Prema stanju od 31. ožujka 2009. godine, u sektoru trgovine bile su zaposlene 101.082 žene, od toga je 19,7\% radilo na određeno vrijeme (DZS, 2009.). U trgovini je, što se moglo i očekivati, najviše žena zaposleno u trgovini na malo, gdje od 66.165 njih $23,2 \%$ radi na određeno vrijeme. U prerađivačkoj industriji zaposleno je 83.346 žena, od toga ih 15,9\% radi na određeno vrijeme. U obrazovanju je zaposleno 78.711 žena, a od toga ih $10,8 \%$ radi na određeno vrijeme. U djelatnosti zdravstvene zaštite i socijalne skrbi ukupno je zaposleno 79.778, od toga su $79,2 \%$ žene. Od ukupnoga broja žena zaposlenih u ovoj djelatnosti samo ih $10,8 \%$ radi na određeno vrijeme. $U$ financijskim djelatnostima i djelatnosti osiguranja zaposleno je 26.373 žena, od toga ih $6,8 \%$ radi na određeno vrijeme. U djelatnosti pružanja smještaja te pripreme i usluživanja hrane radi 20.950 žena, od toga $17,3 \%$ na određeno vrijeme.

2 Činjenica je da su u uzorku podzastupljene ispitanice koje rade $\mathrm{u}$ poljoprivrednom sektoru, no kako njima problem usklađivanja profesionalnih i obiteljskih uloga nije toliko izražen, to ne smatramo relevantnim za dokazivanje osnovnih istraživačkih hipoteza.

${ }^{3}$ Rezultati zbog velikoga broja tablica nisu prikazani.

4 Svjesni smo činjenice da su to želje, no to je prije svega uvjetni pokazatelj.

\section{LITERATURA}

Ahn, N. i Mira, P. (2002.), A Note on the Changing Relationship between Fertility and Female Employment Rates in Developed Countries. Journal of Population Economics, 15 (4): 667-682.

Dobrotić, I., Matković, T. i Baran, J. (2010.), Zaposlenost žena i pristup sustavu predškolske skrbi za djecu u Hrvatskoj: postoji li veza? Revija za socijalnu politiku, 17 (3): 363-384.

Dorbritz, J. (2008.), Germany: Family Diversity with Low Actual and Desired Fertility. Demographic Research, 19 (26): 557-598.

DZS (2010.), Zaposlenost i plaće u 2009. Statistička izvješća 1419. Zagreb: Državni zavod za statistiku, 2010.

Engelhardt, H. i Prskawetz, A. (2004.), On the Changing Correlation between Fertility and Female Employment over Space and Time. European Journal of Population, 20 (1): 35-62.

Esping-Andersen, G. (1999.), Social Foundations of Postindustrial Economies, Oxford: Oxford University Press.

Esping-Andersen, G. (2002.), A Child-Centred Social Investment Strategy. U: G. Esping-Andersen, D. Gallie, A. Hemerijck i J. Myles (ur.), Why do We Need a Welfare State (str. 26-67), Oxford: Oxford University Press.

Esping-Andersen, G. (ur.) (2007.), Family Formation and Family Dilemmas in Contemporary Europe, Bilbao: Fundacio'n BBVA. 
DRUŠ. ISTRAŽ. ZAGREB GOD. 20 (2011), BR. $1(111)$

STR. 3-23

AKRAP, A.: SEKTOR ZAPOSLENOSTI..
Eurostat (2008.), The Life of Women and Men in Europe. A Statistical Portrait, Eurostat: European Commission.

Eurostat (2010.), New Cronos Database, Population and Social Conditions. Dostupno online na: http://epp.eurostat.ec.europa.eu.

Galić, B. i Nikodem, K. (2007.), Identifikacija standarda diskriminacije žena pri zapošljavanju, Istraživački izvještaj, Vlada Republike Hrvatske, Ured za ravnopravnost spolova, Zagreb. http://www.ured-ravnopravnost.hr/ slike/File/istrazivanja/istr_izvj_ident_sand_dis.pdf (10. 5. 2010.).

Gauthier, A. H. (1996.), The State and the Family: A Comparative Analysis of Family Policies in Industrialized Countries, New York: Oxford University Press.

Hakim, C. (2003.), Preference Theory: A New Approach to Explaining Fertility Patterns. Population and Development Review, 29 (3): 349-374.

HGK (2009.), Distributivna trgovina, 2009. Hrvatska gospodarska komora, sektor za trgovinu, Zagreb. Dostupno online na: http://hgk. biznet.hr/hgk/fileovi/15524.pdf

Hoem, J., Neyer, G. i Andersson, G. (2006.), The Relationship between Educational Field, Educational Level, and Childlessness Among Swedish Women Born in 1955-59. Demographic Research, 14 (15): 331-380.

Hoffmann-Nowotny, H.-J. (1980.), Ein theoretisches Modell gesellschaftlichen und sozialen Wandels. U: G. Hischier, R. Levy i W. Obrecht (ur.), Weltgesellschaft und Sozialstruktur (str. 483-502), Festschrift zum 60. Geburtstag von Peter Heintz. Diessenhofen: Rüegger.

Kerovec, N. (2003.), (Ne)jednakost žena na tržištu rada. Revija za socijalnu politiku, 10 (3): 263-282.

Knodel, J. (1997.), A Case for Nonanthropological Qualitative Methods for Demographers. Population and Development Review, 23 (4): 847-853.

Lappegard, T. (2006.), Studies on Fertility and Childcare in Contemporary Norway. Register Analyses, PhD Dissertation, Oslo: University of Oslo.

Leinert Novosel, S. (2003.), Politika zapošljavanja žena. Politička misao, 40 (3): 103-127.

Martín García, T. (2010.), The Impact of Occupational Sex-Composition on Women's Fertility in Spain. European Societies, 12 (1): 113-133.

Martín García, T. i Baizán, P. (2006.), The Impact of the Type of Education and of Educational Enrolment on First Births. European Sociological Review, 22 (3): 259-275.

Matković, T. (2003.) Restrukturiranje rada? Transformacija strukture zaposlenosti. Revija za socijalnu politiku, 10 (2): 161-184.

Matković, T. (2007.), Obuhvat sustavom predškolske skrbi u Hrvatskoj, 1989.-2005. Revija za socijalnu politiku, 14 (1): 123-135.

Matković, T. (2008.), Tko što radi? Dob i rod kao odrednice položaja na tržištu rada u Hrvatskoj. Revija za socijalnu politiku, 15 (3): 479-502.

McDonald, P. (2000.), Gender Equity in Theories of Fertility Transition. Population and Development Review, 26 (3): 427-439.

Mendras, H. (2004.), Europa i Europljani: sociologija Zapadne Europe, Zagreb: Masmedia. 
DRUŠ. ISTRAŽ. ZAGREB GOD. 20 (2011) BR. $1(111)$

STR. 3-23

AKRAP, A.: SEKTOR ZAPOSLENOSTI..
Neyer, G. R. i Andersson, G. (2008.), Consequences of Family Policies on Childbearing Behaviour: Effects or Artifacts? Population and Development Review, 34 (4): 699-724.

Randall, S. i Koppenhaver, T. (2004.), Qualitative Data in Demography. Demographic Research, 11 (3): 57-96.

Stropnik, N. i Sambt, J. (2007.), Parental Leave and Child Benefit: Attitudes, Preferences and Possible Impact. Revija za socijalnu politiku, 14 (3/4): 347-371.

Wertheimer-Baletić, A. (1990.), Populacijska politika - znanstvena utemeljenost, osnove prijedloga ciljeva i mjera. U: Demografski faktori razvoja Hrvatske. Znanstvene osnove dugoročnog društveno-ekonomskog razvoja Hrvatske (str. 37-62), Zagreb: Institut za društvena istraživanja Sveučilišta u Zagrebu i Institut za ekonomska istraživanja Ekonomskog fakulteta u Zagrebu.

\section{Sector of Women's Employment and Fertility in Croatia}

Anđelko AKRAP

Faculty of Economics and Business, Zagreb

The primary purpose of this paper is analyzing the mutual connection between the sector of women's employment and fertility rate in Croatia. The survey was conducted both quantitatively and qualitatively. The quantitative survey is based on a proportional quota sample of 1309 employed women, aged 20-39. The qualitative survey was conducted by using the method of in-depth interview on a sample of 20 participants. Prior to our analysis a theoretical and quantitative overview of the latest European surveys concerning this issue was given. On the manifest level, no (statistically) significant differences in fertility motivation (sum of achieved and intended fertility) were found among the surveyed sectors. However, it has been proven that the sector of employment is an important reason for postponing pregnancy, especially in the commercial sector. The public sector (health and education) provides a certain stability and this is where we find the lowest proportion of women who do not want children, while in the private sector (especially in financial mediation) the proportion of women who do not want children is considerably higher. The paper has also shown a connection between atypical work hours, specifically overtime work, and a decrease in fertility, while a significant correlation between fertility and work during weekends has not been established.

Keywords: fertility, sector of women's employment, employed women, atypical work hours 
DRUŠ. ISTRAŽ. ZAGREB GOD. 20 (2011), BR. $1(111)$

STR. 3-23

AKRAP, A.: SEKTOR ZAPOSLENOSTI..

\section{Berufstätigkeit von Fraven und Geburtenzuwachs in Kroatien}

\section{Anđelko AKRAP}

Wirtschaftswissenschaftliche Fakultät, Zagreb

In dieser Arbeit soll untersucht werden, welche Wechselwirkungen zwischen den Tätigkeitsbereichen berufstätiger Fraven und der Geburtenrate in Kroatien bestehen. Der quantitative Teil der Untersuchung gründet sich auf die Aussagen von 1309 berufstätigen Frauen im Alter von 20 bis 39 Jahren. Der qualitative Untersuchungsteil besteht in Tiefeninterviews mit 20 Umfrageteilnehmerinnen. Der Verfasser schickt seiner Analyse eine theoretische und quantitative Übersicht rezenter europäischer Forschungsarbeiten zu diesem Problem voraus. Zwischen den verschiedenen untersuchten Tätigkeitsbereichen konnten auf Manifestationsebene keine (statistisch) relevanten Unterschiede im Geburtenzuwachs festgestellt werden (Summe der realisierten und der beabsichtigten Geburten). Dennoch erwies sich, dass der jeweilige Tätigkeitsbereich einen wichtigen Grund zur zeitlichen Verschiebung eines Kinderwunsches darstellen kann, insbesondere in der Wirtschaft. Tätigkeiten in staatlichen Einrichtungen (Gesundheitswesen und Bildung) vermögen eine gewisse Sicherheit zu gewähren, sodass dort die wenigsten Fraven ohne Kinderwunsch anzutreffen sind. Im privaten Sektor hingegen (insbesondere im Finanzwesen) liegt die Zahl der Fraven ohne Kinderwunsch erheblich höher. Des Weiteren wird in der Arbeit aufgezeigt, dass zwischen einer untypischen Arbeitszeit, genauer: zwischen der Ableistung von Überstunden, und einer niedrigeren Geburtenrate ein Zusammenhang besteht; hingegen ein Zusammenhang zwischen Wochenendarbeitszeit und niedriger Geburtenrate konnte nicht nachgewiesen werden.

Schlüsselbegriffe: Geburtenrate, berufliche Tätigkeitsbereiche von Fraven, berufstätige Fraven, untypische Arbeitszeiten 